\title{
EVALUATION OF WILLIS POLYGON VARIATIONS ON AORTIC SURGERY PATIENTS WITH
}

$$
\text { UNILATERAL ANTEGRADE CEREBRAL PERFUSION }
$$

\author{
Alper İbrahim TOSYA ${ }^{1}$, Zafer Cengiz ER ${ }^{2}$, Mehmet Ali ÖZATíK ${ }^{3}$ \\ ${ }^{1}$ Koç University Hospital, Department of Cardiovascular Surgery, İstanbul, TURKEY \\ ${ }^{2}$ Bozok University Faculty of Medicine, Department of Cardiovascular Surgery, Yozgat, TURKEY \\ 3Ankara City Hospital, Department of Cardiovascular Surgery, Ankara, TURKEY
}

\begin{abstract}
INTRODUCTION: To determine the effects of wiilis polygon variations on long-term survival in patients with aortic aneurysm and/or aortic dissection operated with the Antegrade Selective Cerebral Perfusion (ASSP) technique

METHODS: Twenty patients with ascending, arcus aneurysm and dissection who underwent antegrade selective cerebral perfusion via the right brachial artery were prospectively studied. Willis polygon variations were detected by cerebral multi-section computed tomographic angiography device. Cooling degrees, cross-clamping, low flow, total perfusion times, postoperative intensive care unit stay, neurologic examination, and hospitalization times were evaluated.

RESULTS: Of the patients, $70 \%$ (14) were male and 30\% (6) were female, with a mean age of 54.20 \pm 10.58 (38-70). Five patients had Stanford type 1 aortic dissection and fifteen patients had ascending and/or aortic aortic aneurysms. The mean cardiopulmonary bypass times of the patients were 146 $\pm 32.9(82-200)$ minutes, the cross-clamp times were $101 \pm 31.6$ (47-165) minutes, and the selective cerebral perfusion times were $26 \pm 7.8(16-45)$ minutes. Only one patient had paresthesia and loss of function in the right hand, and almost complete clinical improvement was observed on the second postoperative day.

DISCUSSION AND CONCLUSION: With this study, we defined the willis polygon variations in the population. As we have determined; If there are three communicating arteries, the variations are not significant. Unless the patients are in the high-risk group, it is not necessary to evaluate the willis polygon variations before the procedure in patients who will undergo surgery with antegrade cerebral perfusion.
\end{abstract}

Keywords: Aortic dissection, aortic aneurysm, polygon of Willis, antegrade cerebral perfusion.

\footnotetext{
Address for Correspondence: Asst. Prof. Zafer Cengiz Er, M.D. Bozok University Faculty of Medicine, Department of Cardiovascular Surgery, Yozgat, Turkey. Phone: +903542127050 Received: 06.11 .2021 E-mail: erzafer2008@gmail.com

0000-0002-0195-9032, Zafer Cengiz Er 0000-0001-7129-1157, Mehmet Ali Özatik 0000-0002-0479-7518.

Please cite this article as following: Tosya Aİ, Er ZC, Özatik MA. Evaluation of Willis polygon variations on aortic surgery patients with unilateral antegrade cerebral perfusion? Turkish Journal of Cerebrovascular Diseases 2021; 27(3): 210-216. doi: 10.5505/tbdhd.2021.02259
} 


\title{
TEK TARAFLI SEREBRAL PERFÜZYON İLE AORT CERRAHISİ UYGULANAN HASTALARDAKI
}

\author{
WILLIS POLİGONU VARYASYONLARININ DEĞERLENDÍRILMESI
}

\section{öz}

GIRIŞ ve AMAÇ: Antegrad Selektif Serebral Perfüzyon (ASSP) tekniğiyle ameliyat edilen aort anevrizması ve/veya aort diseksiyonu hastalarında wiilis poligonu varyasyonlarının uzun dönem sagkalımı üzerine etkilerinin belirlenmesi.

YÖNTEM ve GEREÇLER: Sağ brakiyal arter aracılığı ile antegrad selektif serebral perfüzyon uygulanan asendan, arkus anevrizma ve diseksiyonu bulunan 20 hasta prospektif olarak çalışıldı. Willis poligonu varyasyonları serebral multi-kesit bilgisayarlı tomografik anjiyografi cihazı ile tespit edildi. Soğuma dereceleri, kros-klemp, düşük akım, total perfüzyon süreleri, postoperatif yoğun bakım kalma süresi, nörolojik muayene, hastanede yatış süreleri değerlendirildi.

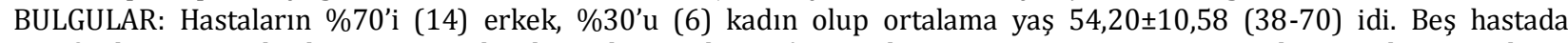
Stanford tip 1 aort diseksiyonu ve onbeş hastada asendan ve/veya arkus aorta anevrzi ması mevcutdu. Hastaların ortalama

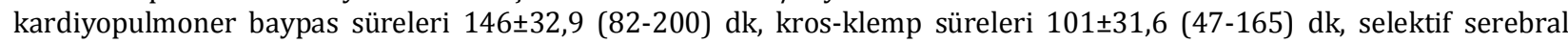
perfüzyon süreleri $26 \pm 7,8$ (16-45) dk idi. Sadece bir hastada sağ elde parestezi ve fonksiyon kaybı gözlendi ve postoperatif ikinci günde tama yakın klinik düzelme gözlendi.

TARTIŞMA ve SONUÇ: : Bu çalışma ile, toplumdaki willis poligonu varyasyonlarını tanımladık. Tespi ettiğimiz üzere; üç adet komunikan arterin bulunması halinde varyasyonların kayda değer önemleri bulunmamaktadır. Hastalar yüksek riskli grupta olmadıkları sürece antegrad serebral perfüzyon ile cerrahi uygulanacak hastalarda willis poligonu varyasyonlarını işlem önce değerlendirmek gerekmemektedir.

Anahtar Sözcükler: Aort diseksiyonu, aort anevrizması, Willis poligonu, antegrad serebral perfüzyon.

\section{INTRODUCTION}

Aortic aneurysm and dissections are generally geriatric diseases that pathologies such as chronic obstructive lung disease, chronic kidney insufficiency, cardiac insufficiency, and hypertension accompany this illness which increases the risk of the surgery.

Deep hypothermic circulatory arrest and retrograde cerebral perfusion are preferred methods for successful aortic surgery, however, these techniques have their inconveniences $(1,2)$. Especially contradictory data about retrograde cerebral perfusion in the presence of cardiopulmonary bypass directed us to use mild hypothermic modified antegrade cerebral perfusion technique.

The aortic arch uses antegrade perfusion technique and also deep hypothermic circulatory arrest and antegrade perfusion with brachial artery cannulation, first of all, arch vein graft anastomose is made and after that from these grafts, antegrade cerebral perfusion or subclavian or axillary artery cannula localization are primary cannulisation preferences (3).

Since 1996 we make operations with right brachial artery cannulation with ascending and archus aortic aneurysm and/or dissections using antegrade selective perfusion technique at our hospital. Neurological cases are the biggest problem in these surgeries however with this technique, the risk decreases down to $2 \%$. In these operations, cerebral perfusion during antegrade cerebral perfusion and especially the flow on the other hemisphere ground Willis polygon integrity. Ophthalmic and leptomeningeal arteries support the other hemisphere's little flows which are hard to measure. The integrity of Willis polygon may be important as here, there are frequent anomaly and hypoplasia.

In this study, we evaluated Willis polygon variations on antegrade selective cerebral perfusion technique patients who have ascending and archus aortic aneurysm with computed tomographic angiography (CTA). Neurological complication risk is high, especially when both anterior and posterior communicating arteries are lacking. This case is rare, however, the results are crucial. As a result, we tried to establish Willis polygon variations with this study.

\section{METHODS}

The study was performed in accordance with Helsinki Declaration. Ethics committee approval was obtained from Yüksek İhtisas University Ethics Committee (Number: EPK-107/11, Date: 06.07.2007). Patient consent were obtained for the study. This study includes prospectively 20 patients who have right brachial artery cannulation with unilateral antegrade selective 
cerebral perfusion with ascending and/or archus aneurysm and dissection. These patients' Willis polygon variations with the CTA technique and its' neurological results are evaluated. $70 \%$ of the patients are male $(4,5)$ and $30 \%$ of the patients are female (6). The average age is $54,20 \pm 10,58$ (38-70), detailed demographic data are shown in Table 1 . Of the patients; 5 have Stanford type 1 aortic dissection and 15 have ascending and/or archus aortic aneurysmal enlargement. Five patients had a major cardiac operation.

Table 1. Demographic data.

\begin{tabular}{lll}
\hline & n & $\mathbf{\%}$ \\
\hline Age(Year) & $54,20 \pm(38-70)$ & \\
Female & 6 & $30 \%$ \\
Male & 14 & $70 \%$ \\
Comorbities & & \\
Hypertension Disease & 16 & $80 \%$ \\
Coranary Artery Disease & 13 & $65 \%$ \\
Choronic Obstructive Lung Disease & 5 & $25 \%$ \\
Diabetes Mellitus & 0 & $0 \%$ \\
Undergone Cardiac Surgey & & \\
Aortic Valve Replacement & 3 & $15 \%$ \\
Coronary Artery Bypass & 2 & $10 \%$ \\
\hline
\end{tabular}

16 patients have hypertension; 5 patients have chronic obstructive lung disease; 13 patients have severe coronary artery disease. None of the patients have diabetes mellitus. Preoperative clinical examinations, echocardiography, cerebral BTA are made. Besides, coronary angiography is made for all of the patients. Cooling degrees, $x$ clamp, low flow, and total perfusion durations are saved (Table 2). Post-operative intensive care and neurological examinations are done.

Table 2. Operative data and surgeries.

\begin{tabular}{ll}
\hline CPB (min) & $146 \pm 32,9(82-200)$ \\
Cross-Clamp (min) & $101 \pm 31,6(47-165)$ \\
Cerebral Perfusion (min) & $26 \pm 7,8(16-45)$ \\
Cooling $\left({ }^{\circ} \mathrm{C}\right)$ & $27 \pm 0,8(25-28)$ \\
Supracoronary graft +hemiarch & $5(25 \%)$ \\
replacement & \\
Supracoronary graft+total arch & $4(20 \%)$ \\
replacement & $3(15 \%)$ \\
Supracoronary graft+hemiarch & \\
replacement+CABG & $2(10 \%)$ \\
Supracoronary graft +CABG+AVR & $2(10 \%)$ \\
Supracoronary graft+AVR & $2(10 \%)$ \\
Bentall+hemiarch replacement & $1(5 \%)$ \\
Total arch replacement & $1(5 \%)$ \\
Supracoronary graft & \\
CPB: Cardiopulmonary bypass, CABG: coronary artery bypass, AVR: aortic valve \\
replacement
\end{tabular}

The hospitalization course is evaluated for each patient and their CTA techniques are made in the Radiology Department of our hospital. Cerebral multislice computed tomographic (MSCT) angiography evaluations are made with MSCT device with 16 detectors (GE Lightspeed Ultra 16, General Electrical Medical Systems, Milwaukee, Wisc.; USA).

After lateral tomogram, the body is scanned starting at inferior foramen magnum level, $1 \mathrm{~cm}$ up to superior lateral ventricular level, through ascending order (caudocranial). Delay time which is used for determining cerebral arteries' maximum contrasting time which means the time between giving the contrast substance and starting MSCT angiography analysis, is calculated by using the bolus tracking technique for each phenomenon. With this aim, a single unenhanced incision is taken from the main carotid distal and 3-5 mm2 ROI (region of interest) is placed to the incision in the carotid artery lumen. For analyzing MSCT angiography, $120 \mathrm{ml}$ iodized contrast substance (Iodixanol, Visipaque $320 \mathrm{mg} / \mathrm{ml}, \mathrm{GE}$ Healthcare Bio-[Sciences], Milwaukee, Wisc.; USA) is given with power injector through the antecubital vein with the intravenous method. 3 seconds after ROI in the distal carotid artery lumen's density reaches to 100 Hounsfield analyzing is started manually. Analysing parameters that are used in the MSCT angiography: $120 \mathrm{kV}, \quad 200-300 \mathrm{~mA}$, matrix; $512 \times 512$, FOV (field of view); $20 \mathrm{~cm}$, detector collimation; $16 \times 0.625 \mathrm{~mm}$, incision size; 0.625 $\mathrm{mm}$, gantry rotation time; 0.5 seconds. MSCT angiography data are sent to another workstation (Advanced workstation 4.2, GE Healthcare, Milwaukee, Wisc.; USA) and 2-dimensional images are taken from axillary images with multiplane reformatting method, and 3-dimensional images are taken with maximum intensity projection (MIP) and volume rendering (VR) methods. All MSCT images are studied by two Radiologists and the diagnosis is made. About measuring cerebral arteries' size approximately the same window is used for all phenomenons (window setting $=1000$, level setting=500).

Statistical analysis: The descriptive statistics method was used with the results such as mean, standard deviation, percentage rate, minimum belonging to the variables. 


\section{RESULTS}

5 patients (25\%) had supracoronary graft hemiarch replacement, 4 (20\%) of them had supracoronary graft total arch replacement, 3 (\%15) of them had supracoronary graft hemiarch replacement with coronary artery bypass, $2(10 \%)$ of the patients had aortic valve replacement with supracoronary graft, $2(10 \%)$ of them had hemiarch replacement with Bentall procedure, 1 (5\%) of them had a total arch replacement and 1 of them (5\%) had supracoronary graft interposition.Three of the patients (15\%) have had an aortic valve replacement, and $2(10 \%)$ of them have had coronary bypass operation.

Patients' approximate $\mathrm{CPB}$ durations are $146 \pm 32.9 \quad(82-200) \mathrm{min}, \mathrm{x}$-clamp durations $101 \pm 31.6 \quad(47-165) \quad \mathrm{min}$, selective cerebral perfusion durations were $26 \pm 7.8(16-45) \mathrm{min}$. Patients are cooled down to $27,3 \pm 0,8(25-28)^{\circ} \mathrm{C}$. Operations and operative data are given in table 2 . Only one of the patients had right-hand paresthesia and function loss. This case is treated on the 2nd day of the postoperative period. The patients' Willis polygon was evaluated in terms of anterior, right, and left communicating arteries. As we analyze variations, 10 patients (50\%) have no left posterior communicating artery, 2 patients $(10 \%)$ have no anterior communicating artery and 3 patients (15\%) have no right posterior communicating arteries (Figure 1, 2). Other patients have no variations. Table 3 shows patients' artery sized and variations on their Willis polygons.

\section{DISCUSSION AND CONCLUSION}

In aortic dissections and aneurysm surgeries, the crucial thing about being successful is protecting the brain and other organs. The brain is the most sensitive organ which can tolerate ischemia for only 5 minutes. Because of this low level of toleration, several techniques are created for the protection of the brain. Although there are techniques which protect the brain in aortic arch surgery, it is still risky for crucial neurological injuries. This may happen globally or focal. If it happens globally it leads to generalizing ischemia or insufficient perfusion $(7,8)$.

For the patients who have complex reconstructions, generally, antegrade brain perfusions with hypothermia are used. Hypothermia may decrease malefic effects for CPB.

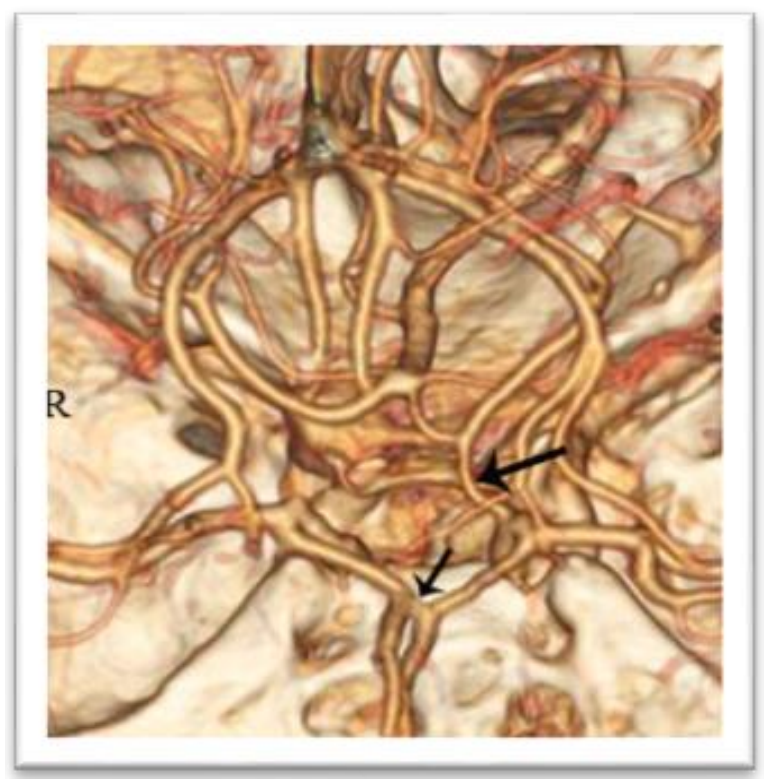

Figure 1: No right posterior communicating artery (Bigger black arrow: Left Posterior Communicating Artery, Smaller arrow: Anterior Communicating Artery).

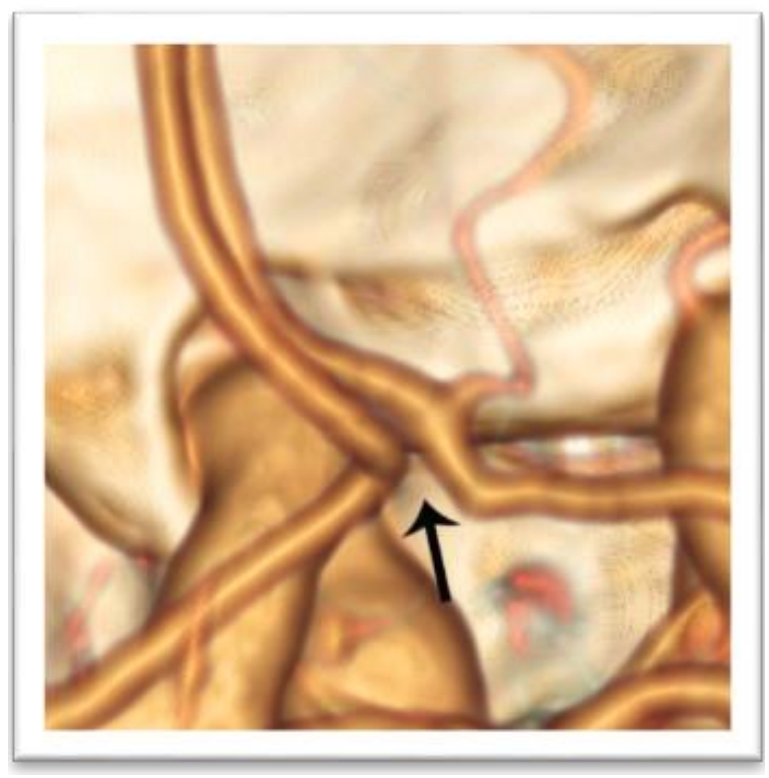

Figure 2: No right anterior communicating artery (arrow).

It is notified that the safe circulatory arrest duration for the human brain is $5 \mathrm{~min}$ at $37^{\circ}$ while $31 \mathrm{~min}$ at $15^{\circ}$. When deep hypothermic circulatory arrest duration surpasses $25 \mathrm{~min}$, the temporary neurological deficit starts. If this duration goes up to $50 \mathrm{~min}$, the risk level increases. For geriatric and hypertensive diabetic patients when the arrest duration surpasses $40 \mathrm{~min}$, the neurological deficit may appear $(9,10,11)$. DHCA has been used 
Table 3. Patients' Willis polygone artery size measurements $(\mathrm{cm})$.

\begin{tabular}{llll}
\hline Patients & Acom & Rightcom & Leftcom \\
\hline Case 1 & 2,3 & null & 2,0 \\
Case 2 & 1,5 & 2,2 & null \\
Case 3 & 1,6 & 1,5 & 0,9 \\
Case 4 & 2,2 & null & 2,0 \\
Case 5 & 2,0 & 2,1 & 1,8 \\
Case 6 & 2,1 & 1,5 & null \\
Case 7 & 2,3 & 1,5 & 2,2 \\
Case 8 & null & 1,4 & 1,8 \\
Case 9 & 2,5 & 1,3 & null \\
Case 10 & 1,3 & 1,3 & null \\
Case 11 & 1,2 & 0,8 & null \\
Case 12 & 2,1 & 1,5 & 1,6 \\
Case 13 & 1,3 & 1,2 & null \\
Case 14 & 2,2 & 2,0 & null \\
Case 15 & 1,0 & 1,0 & 1,2 \\
Case 16 & 1,1 & 1,4 & null \\
Case 17 & 2,0 & 1,2 & null \\
Case 18 & 1,6 & 1,1 & null \\
Case 19 & 1,5 & null & 0,9 \\
Case 20 & null & 0,9 & 1,2 \\
\hline Acom: Anterior communicating artery, Rightcom: Right Anterior communicating \\
artery, Leftcom: Left communicating artery.
\end{tabular}

frequently in the past for arch surgeries. However, in a total arch that uses a long time or surgeries which require thoracic aorta replacement, it is not sufficient for protection. That is why new protection methods have been studied. For this aim, new cerebral perfusion methods are started to be used. As a result of these studies, antegrade selective cerebral perfusion in mild hypothermia with aortic surgery became preferred methods.

Right brachial artery cannulation for selective antegrade perfusion has been used since 1996 at our clinic. The advantage of using the right axillary artery when comparing to femoral arteries, the risk of emboli is lower thanks to atherosclerotic lesions minimal incidences.

Besides, these patients are kept between $26^{\circ} \mathrm{C}-30^{\circ} \mathrm{C}$. The ideal antegrade cerebral perfusion technique should not require deep hypothermia. The cannula that is placed for antegrade perfusion, should not bypass the vertebral artery which provides posterşor cerebral circulation. Cannulas and clamps should not occupy a place in the operation area and arch vein manipulations should be kept at a low level to prevent particle and air emboli $(12,13)$. Our technique is sufficient for these requirements.

One of the important subjects is that whereas contra hemisphere is perfused with this technique or not. The cerebral arterial cycle (CAC) which is also known as Willis cycle is defined by Thomas Willis in 1664.
The blood need of the brain is provided by two vertebral arteries, two internal carotid arteries, and Willis polygon that they create. The anterior communicating artery connects both of the two posterior cerebral arteries. Posterior communicating arteries that connect anterior and posterior circulations are between the middle cerebral artery and posterior cerebral arteries. Besides, there are minor ophthalmic and leptomeningeal collaterals between both of the hemispheres. However, there are variations, comparing to the huge part of the original definition. In the past studies, there are certain relations between Willis polygon variations and some of the cerebrovascular diseases, and in different populations, there are distinctions concerning the incidence of the disease (13-14). This shows that Willis polygon variations are at different incidences in different ethnic and cultural groups.

Contra hemisphere's perfusion during singleacting right side perfusion technique is about Willis polygon state. Besides, Willis polygon variations are frequent (14-16). Macchi and his friends showed that Willis polygon is at the complete configuration in only $47 \%$ of the people with magnetic resonance angiography (MRA) (17).

For healthy people, in the study which is made with MRA, Krabbe-Hartkamp and his friends showed that the complete Willis polygon is $42 \%$, the complete anterior circulation is $74 \%$ and the complete posterior circulation is $52 \%$ (18).

Hoksbergen and his friends notified that anterior flow is insufficient in $5 \%$ of the patients and posterior flow is insufficient in $45 \%$ of patients (19).

In the current study of Urbanski and his friends, 100 patients', who had left carotid artery cannulation and had selective cerebral perfusion, preoperative CTA's are evaluated. In 18 patients, there is abnormal localization in Willis polygon, the same abnormality is found in the posterior communicating artery of 13 patients and both anterior and posterior communicating artery abnormalities are found in 9 patients. Urbanski and his friends divided anatomical variations into 3 groups. In the first group, there are anatomic variations only in a single location (hypoplasia, aplasia). This group requires sufficient collateral nutrition. In the second group, there are abnormalities in posterior pre communicating and communicating arteries on both sides. In the third 
group, on the single or two sides of the Willis polygon both anterior and posterior abnormalities show that left perfusion has insufficient brain circulation (20).

We evaluated multislice CTA with Willis polygon in 20 patients who have aortic surgery and single-sided selective cerebral perfusion with right brachial artery cannulation. $50 \%$ of the patients have no left communicating artery. Only 2 patients have no anterior communicating artery and 3 patients have no right communicating artery. All patients that were diagnosed with an aortic aneurysm in the past are included in the study. Although patients have low output syndrome and their brain is fed from a single carotid artery, there were no neurological complications.

We used the multislice CTA method in this study and evaluated $0.8 \mathrm{~mm}$ sized veins. In anatomical studies, for describing the hypoplasia of collateral arteries or their insufficiency, a $1 \mathrm{~mm}$ peak value is used so far (20-22). According to Hoksbergen and his friends, a non-functional anterior collateral way's median anterior communicating artery's size is $0,4 \mathrm{~mm}$ or less whereas the functional anterior collateral way's size is $1.1 \mathrm{~mm}$. Functional AcomP size is $0,9 \mathrm{~mm}$ whereas non-functional one is $0,6 \mathrm{~mm}$. According to these data, they specified the peak value as $0,4-$ $0,6 \mathrm{~mm}$ (23). Practically, according to Merkkola and his friends' studies, 0,5 and lower sized communicating artery sizes are hypoplastic (24). We specified the peak value as $0.8 \mathrm{~mm}$ (Table 3 ).

Studies of Merkkola and his friends showed Willis polygon's large anatomical variation and become a tool for evaluating intracranial vascular anatomy for the brain's contra hemisphere perfusion ve theoretically, as a result of the anatomic study, it is seen that aortic arch surgery patients have mostly sufficient circulation on their left hemispheres. $14 \%$ of patients with a $0.5 \mathrm{~mm}$ threshold and $17 \%$ of patients with $1 \mathrm{~mm}$ peak value circulations were insufficient. As a result, deep hypothermia is required for cerebral protection. If it is possible, elective patients who are suggested to have aortic arch surgery, cervical and cerebral artery anatomies can be evaluated to form a better risk strategy. That is why, it is notified that CTA, which shows the brain's vascular anatomy, is a good examination for discovering high-risk patients (24).
Urbanski and his friends also indicated that preoperative CTA has negative sides in preoperative diagnostic analysis. It is said that giving radiation to patients increases hospitalization time and fees. They notified that during a hypothermic single-sided circulatory arrest, anatomically, Willis polygon variations have no relation with insufficient cerebral circulation and that is why, for the patients who are going to have aortic arch surgery with singlesided cerebral perfusion, this method does not require to be a standard procedure. At the same time, functional carotid artery occlusion test and neurovascular monitorization are required $(20,24)$.

After these surgeries, temporary or neurological disorders associated with brain hypoperfusion are frequent which increases hospitalization time and fees. The primary aim of ascending and archus surgeries is discharging the patient with minimal neurological complications.

In Yüksek İhtisas Hospital, we operated approximately 400 patients with ascending and archus aneurysm and/or dissection through brachial artery cannulisation with cerebral perfusion technique since 1996. Post-surgery neurological complication incidence is $2 \%$ which is the same rate with regular coronary bypass operations. Different techniques for cerebral perfusion are still, currently, being researched.

As conclusion, with this study, we identified Willis polygon variations in society. We acknowledged that these variations have no remarkable importance if there are 3 communicating arteries. Evaluating Willis polygon variations of patients undergoing surgery via antegrade cerebral perfusion is inessential unless patients have high-risk factors.

\section{REFERENCES}

1. Uysal S, Lin HM, Fischer GW, et al. Selective cerebral perfusion for thoracic aortic surgery: Association with neurocognitive outcome. J Thorac Cardiovasc Surg 2012; 143(5): 1205-1212.

2. Patel BM, Reinert NJ, Al-Robaidi $\mathrm{K}$, et al. Independent predictors of perioperative stroke-related mortality after cardiac surgery. J Stroke Cerebrovasc Dis 2020; 29: 104711.

3. Keeling BW, Leshnower BG, Hunting JC, et al. Hypothermia and selective antegrade cerebral perfusion is safe for arch repair in type A dissection. Ann Thorac Surg 2017; 104 (3): 767-772.

4. Dumfarth J, Ziganshin BA, Tranquilli M, et al. Cerebral 
protection in aortic arch surgery: hypothermia alone suffices. Tex Heart Inst J 2013; 40(5): 564-565.

5. Urbanski PP, Lenos A, Bougioukakis P, et al. Mild-tomoderate hypothermia in aortic arch surgery using circulatory arrest: A change of paradigm? Eur J Cardiothorac Surg 2012; 41(1): 185-191.

6. Hagl C, Ergin MA, Galla JD, et al. Neurologic outcome after ascending aorta/aortic arch operations: effect of brain protection technique in high-risk patients. J Thorac Cardiovasc Surg 2001; 121(6): 1107-1121.

7. Ganapathi AM, Hanna JM, Schechter MA, et al. Antegrade versus retrograde cerebral perfusion for hemiarch replacement with deep hypothermic circulatory arrest: does it matter? A propensity-matched analysis. J Thorac Cardiovasc Surg 2014; 148(6): 2896-2902.

8. Spielvogel D, Halstead JC, Meier M, et al. Aortic arch replacement using a trifurcated graft simple, versatile, and safe. Ann Thorac Surg 2005; 80(1): 90-95.

9. Demirdas E, Sevuk E, Atilgan K, et al. Mid-term results of aortic root repair using the reimplantation technique: Our single-center experience. Turk Gogus Kalp Dama 2016; 24(2): 233-239.

10. Er ZC, Demirdas E, Atilgan $\mathrm{K}$, et al. Koroner arter baypas cerrahisi yapılan hastalarda erken dönemde görülen nörokognitif değişiklikler ile intraoperatif serebral oksimetre değerleri arasındaki ilişkinin araştırılması. Bozok Med J 2017; 7(2): 14-22.

11. Lynch JM, Mavroudis CD, Ko TS, et al. Association of ongoing cerebral oxygen extraction during deep hypothermic circulatory arrest with post-operative brain injury. Semin Thorac Cardiovasc Surg 2021; S10430679(21)00405-6.

12. Baysal A, Doğukan $M$, Temel V, et al. Aort anevrizma onarımı operasyonlarında miyokard ve beyin fonksiyonlarının korunmasında uygulanan farklı yöntemlerin prognoz ve sağkalım üzerine etkileri. Türk Anest Rean Der 2012; 40(4): 234-245.

13. Li YA, Liu ZG, Zhang YP, et all. Differential expression profiles of circular RNAs in the rat hippocampus after deep hypothermic circulatory arrest. Artif Organ. 2021; 45(8): 866-880.

14. Kwon SY, Obeidat AZ, Sekar P, et al. Risk factors for seizures after intracerebral hemorrhage: Ethnic/Racial Variations of Intracerebral Hemorrhage Study. Clin Neurol Neurosurg 2020; 192: 105731.

15. Kim GE, Cho YP, Lim SM. The anatomy of the circle of Willis as a predictive factor for intra-operative cerebral ischemia (shunt need) during carotid endarterectomy Neurol Res 2002; 24(3): 237-40.

16. Pascalau R, Padurean VA, Bartos D, et al. The geometry of the circle of Willis anatomical variants as a potential cerebrovascular risk factor. Turk Neurosurg. 2019; 29(2): 151-158.
17. Naveen SR, Bhat V, Karthik GA. Magnetic resonance angiographic evaluation of circle of Willis: A morphologic study in a tertiary hospital set up. Ann Indian Acad Neurol 2015; 18(4): 391-397.

18. Jalali Kondori B, Azemati F, Dadseresht S. Magnetic resonance angiographic study of anatomic variations of the circle of Willis in a population in Tehran. Arch Iran Med 2017; 20(4): 235-239.

19. Hoksbergen AW, Majoie CB, Hulsmans FJ, et al. Assessment of the collateral function of the circle of Willis threedimensional time-of-flight MR angiography compared with transcranial color-coded duplex sonography. AJNR Am J Neuroradiol 2003; 24(3): 456-62.

20. Urbanski PP, Lenos A, Blume JC, et al. Does anatomical completeness of the circle of Willis correlate with sufficient cross-perfusion during unilateral cerebral perfusion? Eur Jou Car Tho Surg 2008; 33(3): 402-408.

21. Battacharji SK, Hutchinson EC, McCall AJ. The circle of Willis-the incidence of developmental abnormalities in normal and infarchted brains. Brain 1967; 90(4): 747-58.

22. Alpers BJ, Berry RG, Paddison RM. Anatomical studies of the circle of Willis in normal brain arch. Neurol Psychiatry 1959; 81(4): 409-418.

23. Hoksbergen AW, Fulesdi B, Legemate DA, et al. Collateral configuration of the circle of Willistranscranial color-coded duplex ultrasonography and comparison with postmortem anatomy. Stroke 2000; 31(6): 1346-1351.

24. Merkkola P, Tulla H, Ronkainen A, et al. Incomplete circle of willis and right axillary artery perfusion. Ann Thorac Surg 2006; 82(1): 74-79.

Ethics

Ethics Committee Approval: The study was approved by Yüksek İhtisas University Ethics Committee (Number: EPK107/11, Date: 06.07.2007).

Informed Consent: The authors declared that informed consent was signed by the patients.

Copyright Transfer Form: Copyright Transfer Form was signed by all authors

Peer-review: Internally peer-reviewed.

Authorship Contributions: Surgical and Medical Practices: AİT, ZCE, MAÖ. Concept: AİT, ZCE, MAÖ. Design: AİT, ZCE, MAÖ. Data Collection or Processing: AİT, ZCE, MAÖ. Analysis or Interpretation: AİT, ZCE, MAÖ. Literature Search: AİT, ZCE, MAÖ. Writing: AİT, ZCE, MAÖ.

Conflict of Interest: No conflict of interest was declared by the authors.

Financial Disclosure: The authors declared that this study received no financial support.

*This study was presented as an oral presentation at the 8th International Medical and Health Sciences Research Congress (UTSAK) in December 2021. 